\title{
ROOTSTOCK-SCION INTERACTION: 2. EFFECT ON THE COMPOSITION OF CABERNET SAUVIGNON GRAPE MUST ${ }^{1}$
}

\author{
ALBERTO MIELE² \& LUIZ ANTENOR RIZZON ${ }^{3}$
}

ABSTRACT - The interaction between rootstock, scion and the environment may induce different responses to the grapevine physiology and, consequently, to the grape composition. The vineyards of Serra Gaúcha, Brazil, are established in different soil types, each with different morphological and physicochemical attributes. Moreover, the grapevines are grafted onto a diversity of rootstocks. Therefore, this study aimed to determine the effect of 15 rootstocks in the composition of the Cabernet Sauvignon (CS) grape must. The following rootstocks were used: Rupestris du Lot, 101-14 Mgt., 3309 C, 420A Mgt., 5BB K, 161-49 C, SO4, Solferino, 1103 P, 99 R, 110 R, Gravesac, Fercal, Dogridge and Isabel, featuring some genetic diversity altogether. The experimental design was in randomized blocks with 15 treatments, three replicates, 10 vines per plot. The grapes were harvested at maturity for four years, and then crushed for winemaking. Next, the grape musts were centrifuged to separate the solid phase from the liquid phase, which was used for analyses related to sugar, acidity and minerals. The data were submitted to correlation analysis and Principal Component Analysis. The main results from the average of four years show that, in general, the grape musts of the CS/101-14 Mgt., CS/161-49 C, CS/3309 C, CS/Rupestris du Lot and CS/Gravesac combinations had high values of density, total soluble solids, $\mathrm{pH}$ and ${ }^{\circ} \mathrm{Brix} /$ titratable acidity ratio, and low titratable acidity, which was high with CS/99 R, CS/110 R, CS/Dogridge and CS/1103 P. Potassium had higher concentrations in the grape musts of $\mathrm{CS} / \mathrm{SO} 4$ and $\mathrm{CS} / 5 \mathrm{BB} \mathrm{K}$. Titratable acidity did not correlate with density and total soluble solids, but positively correlated with yield. Density, total soluble solids, and the concentration of potassium were positively correlated with $\mathrm{pH}$.

Index terms: Vitis vinifera, grapevine, grafting, composition, minerals.

\section{INTERAÇÃO ENTRE PORTA-ENXERTO E COPA: 2. EFEITO NA COMPOSIÇÃO DO MOSTO DA UVA CABERNET SAUVIGNON}

RESUMO - A interação entre o porta-enxerto, a copa e o ambiente pode induzir diferentes respostas à fisiologia da videira e, consequentemente, à composição da uva. Os vinhedos da Serra Gaúcha são estabelecidos em diferentes tipos de solo, cada um apresentando propriedades morfológicas e físico-químicas particulares. Além disso, as videiras são enxertadas em uma grande diversidade de porta-enxertos. Portanto, esta pesquisa teve como objetivo determinar o efeito de 15 porta-enxertos na composição do mosto da uva Cabernet Sauvignon (CS). Utilizaram-se os seguintes porta-enxertos: Rupestris du Lot, Mgt. 101-14, C 3309, Mgt. 420A, K 5BB, C 161-49, SO4, Solferino, P 1103, R 99, R 110, Gravesac, Fercal, Dogridge e Isabel, que, juntos, apresentam certa diversidade genética. O delineamento experimental foi em blocos casualizados, com 15 tratamentos, três repetições e 10 plantas por parcela. As uvas, maduras, foram colhidas durante quatro anos e, após, esmagadas para vinificação. Em seguida, os mostos foram centrifugados para separar a fase sólida da líquida, a qual foi usada para as análises de variáveis relacionadas a açúcar, acidez e minerais. Os dados foram submetidos à análise de correlação e à Análise de Componentes Principais. Os principais resultados da média dos quatro anos mostram que os mostos das combinações CS/Mgt. 101-14, CS/C 161-49, CS/C 3309, CS/Rupestris du Lot e CS/Gravesac tiveram, em geral, maiores valores de densidade, sólidos solúveis totais, $\mathrm{pH}$ e relação ${ }^{\circ}$ Brix/acidez titulável e menores de acidez titulável, a qual foi elevada nos mostos de CS/R 99, CS/R 110, CS/Dogridge e CS/P 1103. As maiores concentrações de potássio foram as dos mostos de uvas provenientes de $\mathrm{CS} / \mathrm{SO} 4$ e CS/K 5BB. A acidez titulável não se correlacionou com a densidade e os sólidos solúveis totais, mas positivamente com a produtividade do vinhedo. $\mathrm{O}$ pH correlacionou-se positivamente com a densidade, os sólidos solúveis totais e a concentração de potássio.

Termos para indexação: Vitis vinifera, videira, enxertia, composição, minerais.

${ }^{1}$ (Paper 012-16). Received January 14, 2016. Accepted Setember 14, 2016

${ }^{2}$ Engo.-Agro., Dr., Embrapa Uva e Vinho, 95701-008. Bento Gonçalves-RS. E-mail: alberto.miele@embrapa.br

${ }^{3}$ Engo.-Agro., Dr., Embrapa Uva e Vinho. Aposentado. E-mail: luiz.rizzon@terra.com.br 


\section{INTRODUCTION}

The vineyards are established with grafted grapevines in most wine regions of the world. This is mainly due to the possibility of the grapevine roots being fed by the insect Daktulosphaira vitifoliae, which may damage the vines and affect the vineyard yield, grape quality and consequently the farm economy. A question thus arises: which rootstock should be used? In fact, the choice of a rootstock by the growers depends on the interaction between the rootstock, the scion and the environment.

Grafting vines may have an effect in different ways, such as in vine physiology, yield components, vigor, fruitfulness, berry size and color, and phenology. However, the vigor induced by the rootstock on scion is the factor most often considered by growers in choosing a rootstock (WINKLER et al., 1974). The effect of rootstocks on vigor and yield components of the Cabernet Sauvignon grapevine grown in the Serra Gaúcha viticultural region has been the object of study (MIELE; RIZZON, 2017). However, research carried out around the world have had conflicting results (TERRA et al., 2003; ORLANDO et al., 2008; JONES et al., 2009; KELLER et al., 2012; SOUZA et al., 2015).

There are research results conducted in Brazil and in other wine-growing regions of the world in relation to grape composition, such as the effect on total soluble solids (SATISHA et al., 2010; LEÃO et al., 2011), titratable acidity and pH (KAMILOGLU, 2012; KELLER et al., 2012; SOUZA et al., 2015), minerals (BAVARESCO et al., 2003; MIELE et al., 2009; KODUR, 2011; KODUR et al., 2013; GONG et al., 2014; MORALES et al., 2014), anthocyanins (OLLAT et al., 2003; CHOU; LI, 2014), amino acids (JOGAIAH et al., 2013), enzymes (JOGAIAH et al., 2014) and biogenic amines (NASSUR et al., 2014). However, these works show results that may differ from one another, which may be due to several factors such as the genetic material used and where experiments are conducted.

The grape must composition gives an idea of the future wine characteristics and its quality potential. The sucrose transported in the vine phloem tissue is broken down inside the fruit into two monosaccharides, glucose and fructose, which are converted into ethanol and carbon dioxide during the alcoholic fermentation. Therefore, sugars are important compounds in enology because they constitute an indicator of grape ripeness and are responsible for the wine strength.

The two main organic acids in grapes are tartaric and malic acids, which account for their
$\mathrm{pH}$ and acidity. The acidity of the wine plays an important role in the conservation and organoleptic properties of the product because it influences the overall wine balance. Both sugars and malic acid are mainly influenced by weather conditions and vineyard yield.

The presence of minerals in grapes is due to the physicochemical characteristics of soils, and their management, and the pesticides applied in the vineyards. The minerals are nutrients for yeasts to complete the process of alcoholic fermentation and they may also confer wine authenticity and characterize a wine-growing region. After fermentation, they may be responsible for problems related to visual aspects and organoleptic characteristics of the wine. In addition, some of them may be toxic when present in high concentrations.

In this sense, this research aimed to determine the effect of 15 rootstocks in the must composition of Cabernet Sauvignon grapevines grown in a Cambissolo soil of Serra Gaúcha.

\section{MATERIAL AND METHODS}

The experiment was carried out for four consecutive years - 1998/1999 to 2001/2002 in Serra Gaúcha, the most important Brazilian viticultural region.

Data related to the formation of the vineyard, such as soil characteristics, planting, trellising, distances between rows and plants, pruning and training grapevines, canopy management, control of diseases, pests and weeds were described in previous paper (MIELE; RIZZON, 2017).

Treatments consisted of Cabernet Sauvignon grapevine grafted on 15 rootstocks, that is, Rupestris du Lot, 101-14 Mgt., 3309 C, 420A Mgt., 5BB K, 161-49 C, SO4, 1103 P, 99 R, 110 R, Gravesac, Fercal, Dogridge, Solferino (local name of an unknown rootstock) and Isabel (Vitis labrusca L.). Actually, Isabel is not a rootstock, but it is the most widely cultivated grapevine (mostly own rooted) in Serra Gaúcha, whose production goes to wineries to make wine and grape juice. Therefore, there were six Vitis species used in this trial, highlighting $V$. riparia, $V$. rupestris and $V$. berlandieri, which means that there was some genetic diversity. The 15 rootstocks used showed desired characteristics by growers, but they certainly do not cover all problems that may exist in the field.

The experimental design was completely randomized blocks, with 15 treatments $(\mathrm{CS} /$ rootstocks), three replicates, 10 grapevines per plot. Thus, the area of each block was $675 \mathrm{~m}^{2}$ and the 
whole experiment was $2,025 \mathrm{~m}^{2}$.

In February or March, depending on the year, the grapes of all treatments were harvested on the same day. They were then weighted $(\mathrm{kg}$. vine $^{-1}$ ) with a dynamometer and taken to the winery for processing. Subsequently, the grape must samples were immediately collected and sent to the laboratory, where they were centrifuged to separate the solid phase and the liquid phase, from which analyses were performed. Variables related to sugar, acidity and minerals were evaluated. Total soluble solids were determined by an Abbe refractometer (American Optical Corporation), with temperature correction; density $\left(\mathrm{g} \cdot \mathrm{mL}^{-1}\right)$, by a Paar densimeter, with temperature correction as well; titratable acidity (meq. $\mathrm{L}^{-1}$ ), by titration; and $\mathrm{pH}$, by a Corning $\mathrm{pHmeter}$ (RIBÉREAU-GAYON et al., 1982). The ${ }^{\circ}$ Brix/ titratable acidity ratio was calculated by the formula ${ }^{\circ} \mathrm{Brix} /($ titratable acidity x 0.0075 ).

Cations (mg. $\mathrm{L}^{-1}$ ) were determined by a Perking Elmer atomic absorption spectrophotometer working in a flame atomizing module. $\mathrm{K}, \mathrm{Na}$ and $\mathrm{Rb}$ were analysed by flame emission and $\mathrm{Ca}, \mathrm{Mg}$, $\mathrm{Mn}, \mathrm{Fe}, \mathrm{Cu}$ and $\mathrm{Zn}$, by atomic absorption (PERKIN ELMER, 2000). Recommended proportions of acetylene/air mixtures were used for the different chemical elements. $\mathrm{Mn}, \mathrm{Cu}, \mathrm{Fe}, \mathrm{Zn}$ and $\mathrm{Rb}$ were analysed by directly injecting the grape must to the apparatus; $\mathrm{Mg}, \mathrm{K}$ and $\mathrm{Na}$ were diluted in deionized ultra-pure MilliQ water prior to their determination; for $\mathrm{Ca}$ analysis, grape must was diluted in a solution of lanthanum oxide and hydrochloric acid provided by Merck (ORDOÑEZ et al., 1983). P (mg.L $\left.\mathrm{L}^{-1}\right)$, by UV/VIS spectrophotometry (RIBÉREAU-GAYON et al., 1998). Atomic absorption standards were from Merck and mineral concentrations were calculated on the basis of calibration curves for each element specified above.

Grape must data were submitted to the Principal Component Analysis. In addition, correlations among variables were determined.

\section{RESULTS AND DISCUSSION}

The Principal Component Analysis (PCA) shows that the rootstock effect on the composition of the Cabernet Sauvignon grape must varied from year to year. Considering the average of four years, PCs 1 , 2 and 3 accounted for $66.97 \%$ of the total variation in $1999,65.69 \%$ in $2000,69.28 \%$ in 2001 and $67.84 \%$ in 2002 , representing $66.48 \%$ of the average of four years. Therefore, the effects of other PCs were not negligible at all because they represented about onethird of the total variation.
Although there have been different effects of rootstock in the Cabernet Sauvignon grape must composition each year, it can be seen that the CS/10114 Mgt. combination had higher levels of density, total soluble solids and ${ }^{\circ} \mathrm{Brix} /$ titratable acidity ratio in the first three years. This behavior may have been due to the low to medium vigor of this rootstock, which favors a relatively earlier grape maturity. On the other hand, it was found that the rootstock effect on the other assessed variables was erratic year to year. Based on the average data of four years, the three main PCs (Figure 1) show that, in general, density, total soluble solids, $\mathrm{pH}$ and ${ }^{\circ} \mathrm{Brix} /$ titratable acidity ratio values were higher with $\mathrm{CS} / 101-14 \mathrm{Mgt}$., CS/161-49 C, CS/3309 C, CS/Rupestris du Lot and $\mathrm{CS} /$ Gravesac and titratable acidity was higher with CS/99 R, CS/110 R, CS/Dogridge and CS/1103 P.

In general, most researches have showed that there was no effect, or little one, of the rootstock on the total soluble solids of the grape must (NUZZO; MATTHEWS, 2006; SATO et al., 2008; SATISHA et al., 2010; DIAS et al., 2012; KELLER et al., 2012; BERDEJA et al., 2014; CHOU; LI, 2014). However, other works showed that the total soluble solids were significantly affected by the rootstock (REYNOLDS; WARDLE, 2001; ALVARENGA et al., 2002; OLLAT et al., 2003; KODUR et al., 2013; BERDEJA et al., 2014). These last findings match with results of the present work where PCA shows density and total soluble solids being higher with some combinations. In fact, differences of 0.0051 g.mL ${ }^{-1}(+0.47 \%)$ for density and $1.1^{\circ} \mathrm{Brix}(+5.91 \%)$ were detected between CS/101-14 Mgt. and CS/ Isabel (Table 1). Yield and total soluble solids of CS/Isabel were $21 \%$ and $5.6 \%$, respectively, lower than those of CS/101-14 Mgt. This result was not expected because it is well known that, in general, higher yields give lower total soluble solids (MIELE; RIZZON, 2013). Because of this, it is not advisable to recommend the cv. Isabel as rootstock for Vitis vinifera varieties, at least for Cabernet Sauvignon grown in a Cambissolo soil of Serra Gaúcha. In fact, this variety is cultivated on its own roots by grape growers in this region to produce wine and grape juice. On the other hand, the musts of $\mathrm{CS} / 1103 \mathrm{P}$ and CS/99 R combinations showed higher yields and lower total soluble solids than CS/101-14 Mgt. which are in accordance with prior experiments carried out with Cabernet Sauvignon in similar soil conditions (MIELE; RIZZON, 2013). Density and total soluble solids showed correlation $(\mathrm{r}=0.96, \mathrm{p}<0.05)$ between them, and total soluble solids was correlated $(\mathrm{p}<$ $0.05)$ with ${ }^{\circ}$ Brix/titratable acidity ratio $(\mathrm{r}=0.70)$ and $\mathrm{pH}(\mathrm{r}=0.52)$. 
The titratable acidity of the Cabernet Sauvignon grape must was mainly higher with CS/99 R, CS/110 R, CS/Dogridge and CS/1103 P (Figure 1, Table 1). These results are in accordance with the ones of Mota et al. (2009) showing that higher titratable acidity values were found in the grape must of Folha de Figo (syn. Ives), an American variety, grafted on the IAC 572 Jales rootstock. However, it was also shown that titratable acidity was not strongly affected by rootstocks (REYNOLDS; WARDLE, 2001) or it had no effect on it at all (LEÃO et al., 2011; KAMILOGLU, 2012). Moreover, grapes from own-rooted Kyoho grapevines had lower titratable acidity when compared with those grafted on the rootstock 1202 (CHOU; LI, 2014).

The $\mathrm{pH}$ had similar behavior than titratable acidity, that is, it was higher or lower depending on the rootstock (ALVARENGA et al., 2002) or very low differences were found among them (REYNOLDS; WARDLE, 2001). It was also demonstrated that own-rooted grapevines showed higher $\mathrm{pH}$ compared with grafted Merlot and Chardonnay (KELLER et al., 2012), which result goes in the same direction as those of Chou and $\mathrm{Li}$ (2014). Both $\mathrm{pH}$ and acidity may be indirectly affected by rootstocks through modification of the scion vigor (KELLER, 2010).

Titratable acidity and $\mathrm{pH}$ reflect the concentrations of free organic acids, mainly tartaric and malic, present in grapes. The titratable acidity was not correlated ( $>>0.05)$ with density, total soluble solids and $\mathrm{pH}$ as it could be supposed, but it was $(\mathrm{p}<0.05)$ with ${ }^{\circ}$ Brix/titratable acidity ratio $(\mathrm{r}=$ $-0.95)$ and yield $(\mathrm{r}=0.53)$. The $\mathrm{pH}$ showed correlation $(\mathrm{p}<0.05)$ with the concentration of $\mathrm{K}(\mathrm{r}=0.71)$. Titratable acidity and $\mathrm{pH}$ values may have different behavior because $\mathrm{pH}$ indicates the real concentration of $\mathrm{H}^{+}$ions that are ionized or dissociated in the solution while titratable acidity estimates the quantity of titratable acids.

Although some minerals, such as $\mathrm{Ca}, \mathrm{Mg}$, $\mathrm{Fe}$ and $\mathrm{Cu}$, had factor coordinates values (based on correlations) considered more or less high, it is not advisable to interpret this result as a rootstock effect. The differences among their concentrations were not so expressive (Table 2), and some of them, especially $\mathrm{Ca}, \mathrm{Mg}$ and $\mathrm{Cu}$ were present in the Bordeaux mixture applied to the end of the growing season for controlling diseases. Indeed, the results of this study did not show considerable effect of the rootstock in most analysed minerals that generally agree with previous work where there was no significant effect of eight rootstocks on the levels of macronutrients in berries of Cabernet Sauvignon (MIELE et al., 2009). It was also demonstrated that the effect of the rootstock on $\mathrm{N}$ change levels was not consistent among sites (LAMBERT et al., 2008). However, the Brazilian rootstocks IAC 313 Tropical and IAC 5716 Jundiaí favored higher contents of $\mathrm{Ca}$ and $\mathrm{S}$ and IAC 572 Jales and IAC 571-6 Jundiaí higher of $\mathrm{Cu}$ in Niagara Rosada grapes (TECCHIO et al., 2014); the $P$ accumulation showed a significant increase in vines grafted on the Harmony rootstock following a flood treatment (MORALES et al., 2014); skin of Riparia Sauvage showed higher contents of B, Fe and Mn, Berlandieri x Riparia Szilágyi 157 Pécs of $\mathrm{Cu}$, and Vitis berlandieri higher of Zn (FEKETE et al., 2013).

The concentration of $\mathrm{K}$ was higher in the grape musts of the combinations $\mathrm{CS} / \mathrm{SO} 4$ and CS/5BB K (Figure 1, Table 2). Its concentration in grapevine tissues may be controlled by rootstocks due to differences in assimilation by their root systems and the capacity of scion to accumulate minerals in leaves (DELAS; POUGET, 1984), and its presence in shoots is due to the transport from the roots instead of existing differences in uptake or translocation (KODUR, 2011). This clearly means that there should have been an effect of the scion on the activity of the rootstock. Its concentration in grape musts was also dependent on the rootstock (BRANCADORO et al., 1994; KODUR et al., 2013; TECCHIO et al., 2014), but it was not consistent among sites, where differences in soil texture and nutrient availability had impact on this cation (LAMPERT et al., 2008). Yet, the concentration of K in the grape must have had no significant correlation with its content in the grapevine petiole (WALKER; BLACKMORE, 2012).

Differences related to sugar, acidity and minerals found among these experiments could be due, directly or indirectly, to the genetic diversity of scions and rootstocks and their inter-relationships, the soil and climate conditions of each trial, grapevine canopy management, crop load and pesticides applied on grapevines to control pests and diseases.

Results of this research show that all rootstocks evaluated had good affinity and may be used, except for Isabel for at least the Cabernet Sauvignon grapevine grown in the soil and climate conditions the experiment was carried out. Since the Fusarium agent is a problem in many soils of the Serra Gaúcha wine region, the 1103 P rootstock is indicated nowadays. However, if the soil is free of this fungus, a diversity of rootstocks can be used according to their characteristics and the crop objective. It is advisable to consider that grafting may influence the vigor of the scion in such a way that a weak-growing rootstock retards growth of a stronger-growing one and a strong-growing rootstock 
increase grapevine growth (WINKLER et al., 1974). Vigor may induce leaf formation and increase canopy density, which may have influence the grape and wine quality. In short, the choice of a rootstock should be made in such a way as to facilitate their adaptation to the soil, climate factors and grape production goals.
Overall, PCA shows that there was a differential effect of the rootstock on some variables related to must composition of Cabernet Sauvignon grape. However, in general, these differences were not so remarkable, but even if they had been, only the winemaking and the wine physicochemical composition and sensory characteristics would allow saying that these results are significant for the winemaker.
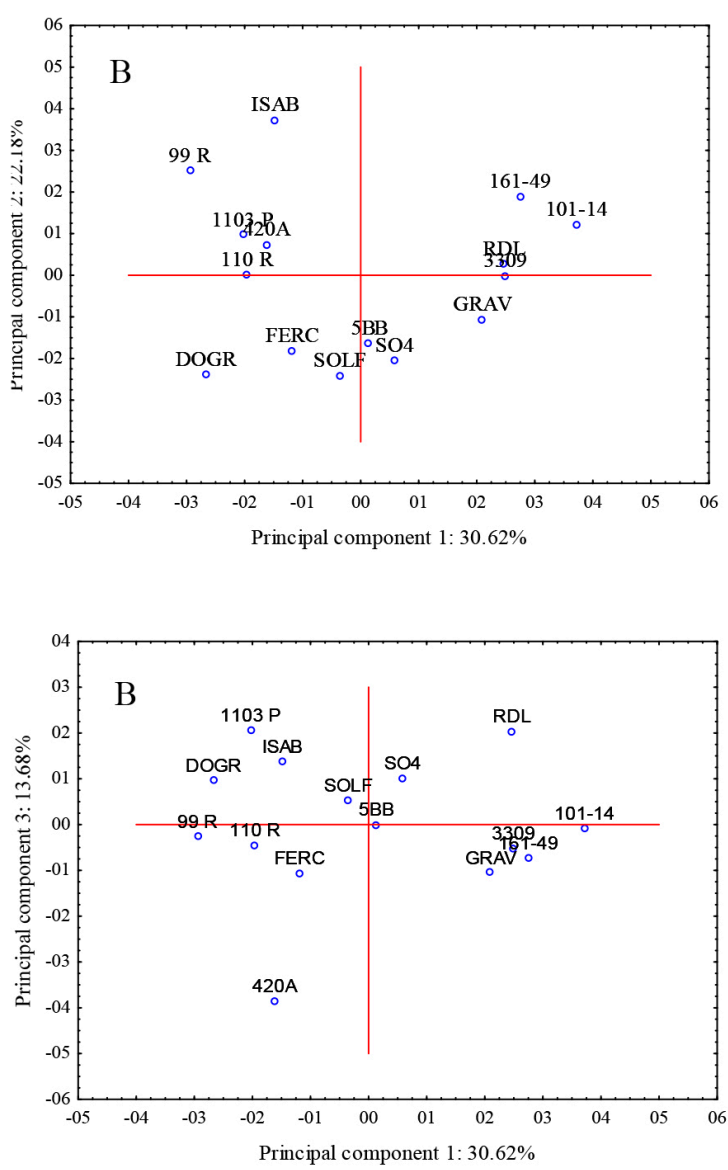

FIGURE 1-Projection of the variables (A) and musts of grapes (B), average data from 1999 to 2002, on the planes formed by the principal components $1 \times 2$ and $1 \times 3$. Legend of variables: $\mathrm{DEN}=$ density, $\mathrm{BRX}=$ total soluble solids, $\mathrm{TA}=$ titratable acidity, $\mathrm{BTA}=\mathrm{Brix} /$ titratable acidity ratio, $\mathrm{PH}=\mathrm{pH}$, $\mathrm{YED}=$ yield, $\mathrm{P}=$ phosphorus, $\mathrm{K}=$ potassium, $\mathrm{Ca}=$ calcium, $\mathrm{Mg}=$ magnesium, $\mathrm{Na}=$ sodium, $\mathrm{Mn}=$ manganese, $\mathrm{Cu}=$ copper, $\mathrm{Fe}=$ iron, $\mathrm{Zn}=$ zinc and $\mathrm{Rb}=$ rubidium. Legend of Cabernet Sauvignon/Rootstock combinations: $\mathrm{RDL}=$ Rupestris du Lot, GRAV $=$ Gravesac, FERC= Fercal, DOGR $=$ Dogridge, $\mathrm{ISAB}=$ Isabel, $\mathrm{SOLF}=$ Solferino, $101-14=1101-14$ Mgt., $3309=$ $3309 \mathrm{C}, 420 \mathrm{~A}=420 \mathrm{~A}$ Mgt., 5BB= 5BB K, 161-49=161-49 C, SO4, 1103 P, $99 \mathrm{R}$ and $110 \mathrm{R}$. 
TABLE 1- Rootstock effect on the yield and physicochemical composition of the Cabernet Sauvignon grape must over four years (1999-2002).

\begin{tabular}{lcccccc}
\hline \multicolumn{1}{c}{ Rootstock } & $\begin{array}{c}\text { Density } \\
\left(\mathrm{g} . \mathrm{mL}^{-1}\right)\end{array}$ & $\begin{array}{c}\text { Total soluble } \\
\text { solids }\left({ }^{\circ} \text { Brix }\right)\end{array}$ & $\begin{array}{c}\text { Titratable acidity } \\
\left(\text { meq. } \mathrm{L}^{-1}\right)\end{array}$ & $\begin{array}{c}{ }^{\circ} \text { Brix/ } \\
\text { Titratable } \\
\text { acidity }\end{array}$ & pH & $\begin{array}{c}\text { Yield/Vine } \\
(\mathrm{kg})\end{array}$ \\
\hline Rupestris du Lot & $1.0834 \pm 0.0079^{1}$ & $19.3 \pm 1.7$ & $126 \pm 17$ & $20.4 \pm 4.5$ & $3.33 \pm 0.05$ & $9.68 \pm 2.92$ \\
101-14 Mgt. & $1.0854 \pm 0.0093$ & $19.7 \pm 2.0$ & $122 \pm 20$ & $21.5 \pm 5.4$ & $3.29 \pm 0.07$ & $9.97 \pm 3.52$ \\
3309 C & $1.0844 \pm 0.0077$ & $19.5 \pm 1.9$ & $126 \pm 18$ & $20.6 \pm 5.0$ & $3.30 \pm 0.05$ & $8.15 \pm 4.07$ \\
420A Mgt. & $1.0829 \pm 0.0074$ & $19.2 \pm 1.6$ & $133 \pm 18$ & $19.2 \pm 4.8$ & $3.24 \pm 0.03$ & $9.68 \pm 4.49$ \\
5BB K & $1.0833 \pm 0.0094$ & $19.2 \pm 2.2$ & $130 \pm 18$ & $19.7 \pm 5.7$ & $3.31 \pm 0.06$ & $9.50 \pm 4.99$ \\
161-49 C & $1.0847 \pm 0.0099$ & $19.3 \pm 2.5$ & $124 \pm 20$ & $20.8 \pm 6.7$ & $3.29 \pm 0.07$ & $8.79 \pm 3.24$ \\
SO4 & $1.0849 \pm 0.0086$ & $19.4 \pm 2.2$ & $133 \pm 17$ & $19.4 \pm 5.3$ & $3.31 \pm 0.08$ & $11.82 \pm 5.42$ \\
Solferino & $1.0832 \pm 0.0081$ & $19.2 \pm 1.9$ & $131 \pm 16$ & $19.5 \pm 5.0$ & $3.29 \pm 0.05$ & $13.17 \pm 5.64$ \\
1103 P & $1.0813 \pm 0.0087$ & $18.9 \pm 1.9$ & $133 \pm 19$ & $18.9 \pm 4.6$ & $3.28 \pm 0.04$ & $10.37 \pm 3.07$ \\
99 R & $1.0815 \pm 0.0085$ & $18.9 \pm 2.0$ & $134 \pm 26$ & $18.8 \pm 5.9$ & $3.24 \pm 0.05$ & $11.02 \pm 3.76$ \\
110 R & $1.0826 \pm 0.0086$ & $19.0 \pm 1.8$ & $133 \pm 22$ & $19.0 \pm 5.8$ & $3.24 \pm 0.06$ & $10.82 \pm 4.17$ \\
Gravesac & $1.0847 \pm 0.0097$ & $19.6 \pm 2.2$ & $128 \pm 20$ & $20.4 \pm 5.8$ & $3.32 \pm 0.03$ & $11.10 \pm 3.72$ \\
Fercal & $1.0821 \pm 0.0077$ & $19.1 \pm 1.8$ & $136 \pm 21$ & $18.7 \pm 4.9$ & $3.27 \pm 0.05$ & $10.89 \pm 4.89$ \\
Dogridge & $1.0821 \pm 0.0066$ & $19.0 \pm 1.5$ & $136 \pm 17$ & $18.6 \pm 4.0$ & $3.31 \pm 0.08$ & $10.35 \pm 4.87$ \\
Isabel & $1.0803 \pm 0.0086$ & $18.6 \pm 2.0$ & $127 \pm 17$ & $19.5 \pm 5.3$ & $3.26 \pm 0.06$ & $7.88 \pm 3.17$ \\
\hline
\end{tabular}

${ }^{1}$ Mean \pm standard deviation.

TABLE 2- Rootstock effect on the mineral composition of the Cabernet Sauvignon grape must over four years (1999-2002).

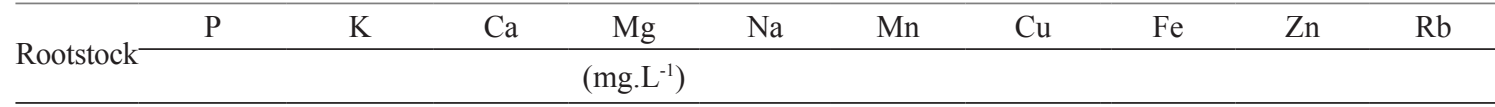

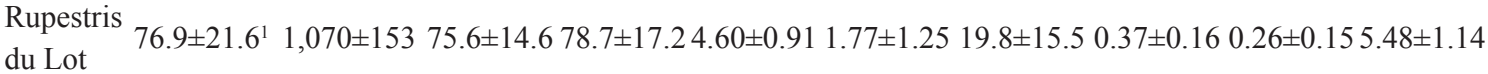

101-14

Mgt.

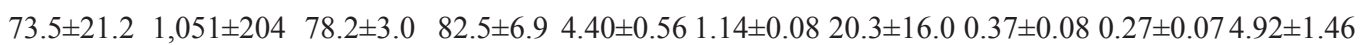

$3309 \mathrm{C} \quad 65.8 \pm 22.6 \quad 1,092 \pm 240 \quad 76.3 \pm 8.6 \quad 79.3 \pm 8.8 \quad 4.28 \pm 0.66 \quad 1.10 \pm 0.07 \quad 20.1 \pm 15.7 \quad 0.37 \pm 0.08 \quad 0.20 \pm 0.095 .19 \pm 1.45$ $420 \mathrm{~A}$

Mgt.

$62.2 \pm 14.4 \quad 976 \pm 150 \quad 59.8 \pm 19.3 \quad 77.2 \pm 7.8 \quad 4.43 \pm 0.760 .98 \pm 0.14 \quad 18.4 \pm 11.4 \quad 0.37 \pm 0.090 .18 \pm 0.044 .23 \pm 0.75$

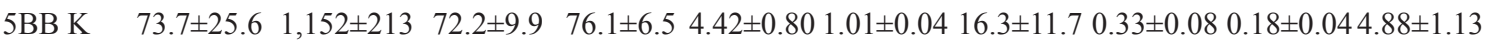

161-49 C $58.4 \pm 26.2 \quad 1,037 \pm 202 \quad 82.0 \pm 14.3 \quad 84.2 \pm 10.94 .47 \pm 0.750 .98 \pm 0.07 \quad 21.2 \pm 17.2 \quad 0.39 \pm 0.090 .21 \pm 0.094 .88 \pm 1.29$

SO4 $\quad 73.4 \pm 27.7 \quad 1,161 \pm 219 \quad 78.9 \pm 8.9 \quad 80.0 \pm 5.6 \quad 4.40 \pm 0.67 \quad 1.01 \pm 0.10 \quad 19.7 \pm 14.4 \quad 0.33 \pm 0.090 .18 \pm 0.095 .23 \pm 1.39$

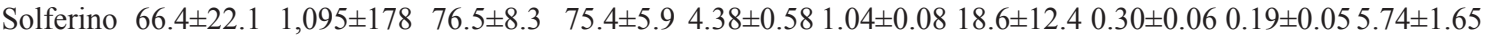

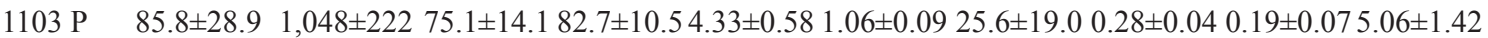

$99 \mathrm{R} \quad 75.6 \pm 25.7 \quad 956 \pm 207 \quad 73.6 \pm 22.580 .8 \pm 12.64 .87 \pm 1.061 .03 \pm 0.1423 .6 \pm 18.20 .34 \pm 0.13 \quad 0.20 \pm 0.064 .28 \pm 0.85$

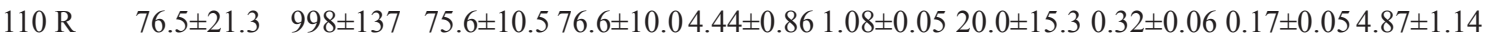

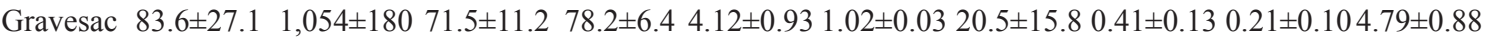

$\begin{array}{llllllllll}\text { Fercal } & 75.6 \pm 19.9 & 1,077 \pm 208 & 71.9 \pm 9.7 & 73.8 \pm 6.2 & 4.24 \pm 0.97 & 1.02 \pm 0.07 & 18.0 \pm 14.0 & 0.40 \pm 0.13 & 0.22 \pm 0.185 .33 \pm 0.96\end{array}$

Dogridge $86.0 \pm 24.3 \quad 1,081 \pm 193 \quad 71.2 \pm 4.0 \quad 75.7 \pm 9.3 \quad 4.81 \pm 1.11 \quad 0.97 \pm 0.10 \quad 17.2 \pm 11.7 \quad 0.34 \pm 0.11 \quad 0.14 \pm 0.055 .62 \pm 1.79$

Isabel $\quad 76.2 \pm 17.0 \quad 1,068 \pm 300 \quad 74.5 \pm 17.686 .3 \pm 11.74 .79 \pm 0.93 \quad 1.10 \pm 0.27 \quad 20.6 \pm 16.4 \quad 0.31 \pm 0.190 .24 \pm 0.164 .35 \pm 0.72$

${ }^{1}$ Mean \pm standard deviation. 


\section{CONCLUSIONS}

Considering the average data from the 1999 to 2002 harvests, the Principal Component Analysis shows that the CS/Isabel combination has the lowest yield and the lowest total soluble solids.

The grape musts of CS/101-14 Mgt., CS/161$49 \mathrm{C}, \mathrm{CS} / 3309 \mathrm{C}, \mathrm{CS} /$ Rupestris du Lot and CS/ Gravesac combinations have, in general, higher values of density, total soluble solids, $\mathrm{pH}$ and ${ }^{\circ} \mathrm{Brix} /$ titratable acidity ratio and lower titratable acidity, which is higher with CS/99 R, CS/110 R, CS/ Dogridge and CS/1103 P.

Density, total soluble solids and $\mathrm{K}$ are positively correlated with $\mathrm{pH}$.

Potassium is higher in the grape musts of CS/ $\mathrm{SO} 4$ and $\mathrm{CS} / 5 \mathrm{BB} \mathrm{K}$ combinations.

\section{ACKNOWLEDGEMENTS}

The authors thank the colleagues of Embrapa Uva e Vinho who worked for nine years by managing grapevines in the vineyard and by performing grape musts analyses for four years, and INRA-Centre des Recherches de Bordeaux for its kindness to provide some vegetative material for this research.

\section{REFERENCES}

ALVARENGA, A.A.; REGINA, M. de A.; FRÁGUAS, J.C.; CHALFUN, N.N.J.; SILVA, A.L. da. Influência do porta-enxerto sobre o crescimento e produção da cultivar de videira Niágara Rosada (Vitis labrusca L. x Vitis vinifera L.), em condições de solo ácido. Ciência e Agrotecnologia, Lavras, v.26, p.1459-1464, 2002. Número especial.

BAVARESCO, L.; GIACHINO, E.; PEZZUTTO, S. Grapevine rootstock effects on lime-induced chlorosis, nutrient uptake, and source-sink relationships. Journal of Plant Nutrition, New York, v.26, n.7, p.1451-1465, 2003.

BERDEJA, M.; HILBERT, G.; LAFONTAINE, M.; STOLL, M.; GOMES, E.; RENAUD, C.; DELROT, $\mathrm{S}$. Effects of drought stress and rootstock genotype on grape berry quality. Acta Horticulturae, The Hague, n.1038, p.375-377, 2014.

BRANCADORO, L.; VALENTI, L.; REINA, A.; SCIENZA, A. Potassium content of grapevine during the vegetative period: the role of the rootstock. Journal of Plant Nutrition, New York, v.17, n.12, p.2165-2175, 1994.
CHOU, M-I.; LI, K-T. Rootstock and seasonal variations affect anthocyanin accumulation and quality traits of 'Kyoho' grape berries in subtropical double cropping system. Vitis, Siebeldingen, v.53, n.4, p.193-199, 2014.

DELAS, J.; POUGET, R. Action de la concentration de la solution nutritive sur quelques caractéristiques physiologiques et technologiques chez Vitis vinifera cv. Cabernet-Sauvignon. II. Composition minérale des organes végétatifs, du moût et du vin. Agronomie, Paris, v.4, n.5, p. 443-450, 1984.

DIAS, F.A.N.; MOTA, R.V. da; FÁVERO. A.C.; PURGATTO, E.; SHIGA, T.M.; SOUZA, C.R. de; PIMENTEL, R.M. de A.; REGINA, M. de A. Videira 'Syrah' sobre diferentes porta-enxertos em ciclo de inverno no sul de Minas Gerais. Pesquisa Agropecuária Brasileira, Brasília, v.47, n.2, p.208215, 2012.

FEKETE, I.; KOVÁCS, B.; ANDRÁSI, D.; BÓDI, E.; RAKONCZÁS, N. Effects of the different grape rootstocks on berry skin $\mathrm{B}, \mathrm{Cu}, \mathrm{Fe}, \mathrm{Mn}$ and $\mathrm{Zn}$ contents of 'Cserszegi fuszeres' cultivar. Scientific Papers. Series B, Horticulture, Bucharest, v.47, p.55-60, 2013.

GONG, H.J.; BLACKMORE, D.H.; CLINGELEFFER, P.R.; SYKES, S.R.; WALKER, R.R. Variation for potassium and sodium accumulation in a family from a cross between rootstocks K 5140 and 140 Ruggeri. Vitis, Siebeldingen, v.53, n.2, p.65-72, 2014.

JOGAIAH, S.; OULKAR, D.P.; BANERJEE, K.; SHARMA, J.; PATIL, A.G.; MASKE, S.R.; SOMKUWAR, R.G. Biochemically induced variations during some phenological stages in Thompson Seedless grapevines grafted on different rootstocks. South African Journal of Enology and Viticulture, Stellenbosch, v.34, n.1, p.36-45, 2013.

JOGAIAH, S.; SHARMA, A.K.; ADSULE, P.G. Rootstock influence on the biochemical composition and polyphenol oxidase activity of 'Thompson Seedless' grapes and raisins. International Journal of Fruit Science, Philadelphia, v.14, n.2, p.133-146, 2014.

JONES, T.H.; CULLIS, B.R.; CLINGELEFFER, P.R.; RÜHL, E.H. Effects of novel hybrid and traditional rootstocks on vigour and yield components of Shiraz grapevines. Australian Journal of Grape and Wine Research, Oxford, v.15, n.3, p.284-292, 2009. 
KAMILOGLU, Ö. The effects of rootstocks and training systems on the growth and fruit quality of the 'Round Seedless' grape. Journal of Food Agriculture and Environment, Helsinki, v.10, n.1, p.350-354, 2012.

KELLER, M. The science of grapevines: anatomy and physiology. Amsterdam: Elsevier, 2010.

KELLER, M.; MILLS, L.J.; HARBERTSON, J.F. Rootstock effects on deficit-irrigated winegrapes in a dry climate: vigor, yield formation, and fruit ripening. American Journal of Enology and Viticulture, Davis, v.63, n.1, p.29-39, 2012.

KODUR, S. Effects of juice $\mathrm{pH}$ and potassium on juice and wine quality, and regulation of potassium in grapevines through rootstocks (Vitis): a short review. Vitis, Siebeldingen, v.50, n.1, p.1-6, 2011.

KODUR, S.; TISDALL, J.M.; CLINGELEFFER, P.R.; WALKER, R.R. Regulation of berry quality parameters in 'Shiraz' grapevines through rootstocks (Vitis). Vitis, Siebeldingen, v.53, n.3, p.125-128, 2013.

LAMBERT, J-J.; ANDERSON, M.M.; WOLPERT, J.A. Vineyard nutrient needs vary with rootstocks and soils. California Agriculture, Sacramento, v.62, n.4, 202-207, 2008.

LEÃO, P.C de S.; BRANDÃO, E.O.; GONÇALVES, N.P. da S. Produção e qualidade de uvas de mesa 'Sugraone' sobre diferentes porta-enxertos no submédio do Vale do São Francisco. Ciência Rural, Santa Maria, v.41, n.9, p.1526-1531, 2011.

MIELE, A.; RIZZON, L.A. Intensidade de poda seca e do desbaste de cacho na composição da uva Cabernet Sauvignon. Revista Brasileira de Fruticultura, Jaboticabal, v.35, n.4, p.1081-1092, 2013.

MIELE, A.; RIZZON, L.A. Rootstock-scion interaction: 1. Effect on the yield components of the Cabernet Sauvignon grapevine. Revista Brasileira de Fruticultura, Jaboticabal, v.39, n.1: (e-820), 2017.

MIELE, A.; RIZZON, L.A.; GIOVANNINI, E. Efeito do porta-enxerto no teor de nutrientes em tecidos da videira 'Cabernet Sauvignon'. Revista Brasileira de Fruticultura, Siebeldingen, v.31, n.4, p.11411149, 2009.
MORALES, M.; TORO, G.; RIQUELME, A.; SELLÉS, G.; PINTO, M.; FERREYRA, R. Effect of different rootstocks on photosynthesis and nutritional response of grapevines cultivar 'Sultanina' under flooding stress. Acta Horticulturae, The Hague, n.1045, p.123-131, 2014.

MOTA, R.V. da; SOUZA, C.R. de; FAVERO, A.C.; SILVA, C.P.C.; CARMO, E.L. do; FONSECA, A.R.; REGINA, M. de A. Produtividade e composição físico-química de bagas de cultivares de uva em diferentes porta-enxertos. Pesquisa Agropecuária Brasileira, Brasília, v.44, n.6, p.576-582, 2009.

NASSUR, R. de C.M.R.; PEREIRA, G.E.; ALVES, J.A.; LIMA, L.C. de O. Chemical characteristics of grape juices from different cultivar and rootstock combinations. Pesquisa Agropecuária Brasileira, Brasília, v.49, n.7, p.540-545, 2014.

NUZZO, V.; MATTHEWS, M.A. Response of fruit growth and ripening to crop level in dry-farmed Cabernet Sauvignon on four rootstocks. American Journal of Enology and Viticulture, Davis, v.57, n.3, p. 314-324, 2006

OLLAT, N.; TANDONNET, J.P.; LAFONTAINE, M.; SCHULTZ, H.R. Short and long term effects of three rootstocks on Cabernet Sauvignon vine behaviour and wine quality. Acta Horticulturae, The Hague, n.617, p.95-100, 2003.

ORDOÑEZ, R.; PANEEQUE, G.; MEDINA, M.; CORRAL, L. Estudio de mostos de vendimia y fermentados de la zona Montilla Moriles: II. K, Ca, $\mathrm{Na}, \mathrm{Mg}, \mathrm{Fe}, \mathrm{Cu}, \mathrm{Zn}$ y $\mathrm{Mn}$. Anales de Edafología y Agrobiología, Madrid, v.42, n.7-8, p.1133-1144. 1983.

ORLANDO, T. das G. S.; PEDRO JUNIOR, M.J.; SANTOS, A.O.; HERNANDES, J.L. Comportamento das cultivares Cabernet Sauvignon e Syrah em diferentes porta-enxertos. Ciência e Agrotecnologia, Lavras, v.32, n.3, p.749-755, 2008.

PERKIN ELMER. Analytical methods for atomic absorption spectrophotometry. Singapore: Perkin Elmer, 2000.

REYNOLDS, A.G.; WARDLE, D.A. Rootstocks impact vine performance and fruit composition of grapes in British Columbia. HorTechnology, Alexandria, v.11, n.3, p.419-427, 2001. 
RIBÉREAU-GAYON, P.; GLORIES, Y.; MAUJEAN, A.; DUBOURDIEU, D. Traité d'œnologie: 2 . chimie du vin; stabilisation et traitements. Paris: Dunod, 1998.

RIBÉREAU-GAYON, J.; PEYNAUD, E.; SUDRAUD, P.; RIBÉREAU-GAYON, P. Traité d'œnologie: sciences et techniques du vin: analyse et contrôle des vins. $2^{\text {nd }}$ ed. Paris: Dunod, 1982. v.1.

SATISHA, J.; SOMKUWAR, R.G.; SHARMA, J.; UPADHYAY, A.K.; ADSULE, P.G. Influence of rootstocks on growth, yield and fruit composition of Thompson Seedless grapes grown in the Pune Region of India. South African Journal of Enology and Viticulture, Stellenbosch, v.31, n.1, p.1-8, 2010.

SATO, A.J.; SILVA, B.J. da; SANTOS, C.E. dos; BERTOLUCCI, R.; SANTOS, R. dos; CARIELO, M.; GUIRAUD, M.C.; FONSECA, I.C. de B.; ROBERTO, S.R. Características físico-químicas e produtivas das uvas 'Isabel' e 'BRS-Rúbea' sobre diferentes porta-enxertos na região norte do Paraná. Revista Brasileira de Fruticultura, Jaboticabal, v.30, n.2, p.553-556, 2008.
SOUZA, C.R. de; MOTA, R.V. da; FRANÇA, D.V.C.; PIMENTEL, R.M. de A.; REGINA, M. de A. Cabernet Sauvignon grapevine grafted onto rootstocks during the autumn-winter season in southeastern Brazilian. Scientia Agricola, Piracicaba, v.72, n.2, p.138-146, 2015.

TECCHIO, M.A.; MOURA, M.F.; TEIXEIRA, L.A.J.; PIRES, E.J.P.; LEONEL, S. Influence of rootstocks and pruning times on yield and on nutrient content and extraction in 'Niagara Rosada' grapevine. Pesquisa Agropecuária Brasileira, Brasília, v.49, n.5, p.340-348, 2014.

TERRA, M.M.; PIRES, E.J.P.; POMMER, C.V.; BOTELHO, R.V. Produtividade da cultivar de uva de mesa Niagara Rosada sobre diferentes portaenxertos, em Monte Alegre do Sul-SP. Revista Brasileira de Fruticultura, Jaboticabal, v.25, n.3, p.549-551, 2003.

WALKER, R.R.; BLACKMORE, D.H. Potassium concentration and $\mathrm{pH}$ inter-relationships in grape juice and wine of Chardonnay and Shiraz from a range of rootstocks in different environments. Australian Journal of Grape and Wine Research, Oxford, v.18, n.2, p.183-193, 2012.

WIKLER, A.J.; COOK, J.A.; KLIEWER, W.M.; LIDER, L.A. General viticulture. Berkeley: University of California, 1974. 